\title{
TAXONOMIC AND NOMENCLATURAL NOTES ON MICONIA CRENATA AND RELATED SPECIES (MELASTOMATACEAE: MICONIEAE) IN THE GREATER ANTILLES
}

\author{
Walter S. Judd \\ Department of Biology and Florida \\ Museum of Natural History \\ University of Florida \\ Gainesville, Florida 32611-7800, U.S.A. \\ lyonia@ufl.edu \\ Lucas C. Majure \\ Desert Botanical Garden \\ 1201 N Galvin Parkway \\ Phoenix, Arizona 85008, U.S.A. \\ Imajure@dbg.org
}

\author{
Gretchen M. Ionta \\ Department of Biological and Environmental Sciences \\ Georgia College and State University, CBX-081 \\ Milledgeville, Georgia 31061, U.S.A. \\ gretchen.ionta@gcsu.edu
}

\author{
Fabián A. Michelangeli \\ Institute of Systematic Botany \\ The New York Botanical Garden \\ 2900 Southern Blvd. \\ Bronx, New York 10458, U.S.A. \\ fabian@nybg.org
}

\section{ABSTRACT}

\begin{abstract}
The nomenclature and phylogenetic placement of five species of Miconieae in the Greater Antilles with conspicuous multicellular, simple, elongate, eglandular or gland-headed hairs, pseudolateral inflorescences, and flowers with elongated calyx teeth, 5-8, white, rounded petals, white, ovate anthers, and purple- or blue-black fruits are considered. These species have traditionally been considered within the polyphyletic genus Clidemia, but are here transferred to Miconia sensu lato. Four new combinations are presented, i.e., Miconia dependens (D. Don) Judd \& Majure, M. erythropogon (DC.) Judd \& Ionta, M. octona (Bonpl.) Judd \& Majure, and M. strigillosa (Sw.) Judd \& Ionta. Finally, we note that the widespread and economically important species previously known as Clidemia hirta (L.) DC., when considered within Miconia, bears the name Miconia crenata (Vahl) Michelang.
\end{abstract}

Key Words: Clidemia, Clidemia hirta, Cuba, Heterotrichum, Hispaniola, Maieta

\section{RESUMEN}

Se considera la nomenclatura y ubicación filogenética de cinco especies de Miconieae de las Antillas Mayores. Estas cinco especies muestran pelos conspicuos, multicelulares, sencillos, eglandulares o glandulares, inflorescencias pseudolaterales, flores con los dientes del cáliz elongados,5-8 pétalos redondeados blancos, anteras aovadas, y frutos morados o negro-azulados. Tradicionalmente estas especies fueron consideradas dentro del género polifilético Clidemia, pero aquí se transfieren las especies a Miconia sensu lato. Se presentan cuatro combinaciones nuevas, Miconia dependens (D. Don) Judd \& Majure, M. erythropogon (DC.) Judd \& Ionta, M. octona (Bonpl.) Judd \& Majure, y M. strigillosa (Sw.) Judd \& Ionta. Finalmente, notamos que la especie ampliamente distribuida y económicamente importante previamente conocida como Clidemia hirta (L.) DC., tiene el nombre de Miconia crenata (Vahl) Michelang., cuando es considerada como parte de Miconia sensu lato.

The genus Clidemia D. Don, like nearly all other genera of Miconieae, has been shown to be highly polyphyletic (Goldenberg et al. 2008; Michelangeli et al. 2008, submitted), a finding in keeping with the history of problematic generic delimitations within the tribe (Cogniaux 1891; Judd 1989; Judd \& Skean 1991). The most workable solution to this classificatory problem (as clearly evident in Figs. 1-3 of Goldenberg et al. 2008) is to place all species of Miconieae within a greatly expanded Miconia Ruiz \& Pav., comprising the DNA-supported clade within Miconieae that can be diagnosed by the synapomorphy of berry fruits (Gamba \& Almeda 2014; Goldenberg et al. 2013; Ionta et al. 2012; Judd et al. 2014a, b, 2015; Majure et al. 2014; Michelangeli et al. 2016).

We here consider the Greater Antillean species formerly placed in Clidemia that have conspicuous, multicellular, simple, elongate, eglandular or gland-headed hairs, sympodial growth, pseudolateral inflorescences, flowers with elongate calyx teeth, 5-8 white, rounded petals, white, ovate anthers, and purple- or blue-black fruits. These species, including the widespread and well-known C. hirta (L.) D. Don, C. capitellata (Bonpl.) D. Don, C. strigillosa (Sw.) DC., and C. octona (Bonpl.) L.O. Williams, have in the twentieth century consistently 
been placed in Clidemia (see, for example, Alain 1957; Almeda 2009; Croat 1978; Gleason 1939; Howard 1989; Liogier 1995, 2000; Moscoso 1943; Proctor 1972; Standley \& Williams 1961; Urban 1921; Wurdack 1973, 1980). These species were placed by Cogniaux (1891) within Clidemia sect. Staphidium (Naudin) Cogn. (the type species of which is C. octona), and later were placed in Clidemia sect. Clidemia by Wurdack (1973). Clidemia neglecta D. Don (= C. capitellata) was selected as the type of the genus Clidemia by Britton and Wilson (1925); this was the first species listed by David Don in his treatment of the genus (Don 1823), and it may have been selected by Britton and Wilson for that reason (following the New York code). Moreover, it perfectly matches Don's generic diagnosis and well represents the morphology of core-Clidemia. We thus agree with their lectotypification, which was unfortunately automatic and invalid. Below, we formally designate Clidemia neglecta D. Don as the type species of Clidemia. We here briefly consider the phylogenetic placement of these Greater Antillean species and propose names for them within an expanded Miconia.

The first author has long suggested that those species of Clidemia with pseudolateral inflorescences (i.e., determinate shoot development and terminal inflorescences with branch elongation due to sympodial growth, and the inflorescences deflexed to a pseudolateral position as the result of the development of an axillary bud immediately below the inflorescence; see Fig. 1 A, B, E, I, J) were not closely related to those species showing indeterminate shoot growth and truly axillary inflorescences (Judd 1986, 1989; Judd \& Skean 1991). This morphology-based hypothesis is now supported, at least in part, by molecular data (Goldenberg et al. 2008; Martin et al. 2008; Michelangeli et al. 2004, 2008, submitted), although the classificatory situation is even more complicated than anticipated given the results of molecular analyses that suggest that pseudolateral inflorescences (and the associated sympodial stem growth) have evolved multiple times in the Miconieae, e.g., in the M. strigillosa group (represented in the Antilles by M. strigillosa (Sw.) Judd \& Ionta and M. dependens (Don) Judd \& Majure), in the M. octona group (represented in the Antilles by M. octona (Bonpl.) Judd \& Majure, M. crenata (Vahl.) Michelang., and M. erythropogon (DC.) Judd \& Ionta), and in the Octopleura clade (Gamba \& Almeda 2014; represented in the Antilles by M. rubescens (Triana) Gamba \& Almeda). These three clades are not each other's closest relatives, but instead they are positioned across the cladogram (Goldenberg et al. 2008; Michelangeli et al., 2008, submitted), with the species of the M. strigillosa group more closely related to Miconia sect. Sagraea (Ionta et al. 2012) than they are to the members of the M. octona group, and the species of the M. octona group perhaps most closely related to many species of Leandra (Martin et al. 2008). The Octopleura clade is most closely related to Miconia s.s. (Gamba \& Almeda 2014; Michelangeli et al. 2008). Additional striking morphological features that apparently have also evolved in parallel among these species of the M. octona and M. strigillosa groups include their conspicuous strigose indumentum and elongate calyx teeth (see Majure et al. 2013; Fig. 1 C, D, F-H, J, K). Thus, despite their phenetic similarity and long tradition of being considered closely related (Cogniaux 1891; Wurdack 1973, 1980), phylogenetic analyses based on DNAsequences do not support a close relationship between the species of the M. octona clade and the M. strigillosa clade, although this hypothesis is preliminary and increased taxon sampling is needed.

In addition to molecular data (Michelangeli et al., submitted), the monophyly of the Miconia strigillosa clade (= Clidemia sect. Clidemia) is supported by the putative synapomorphies of gland-headed hairs on the abaxial leaf surface (but we note that this character has also evolved within the M. octona clade), stellate hairs on the abaxial leaf surface, pseudolateral inflorescences (Fig. $1 \mathrm{I}, \mathrm{J}$ ), and shoots producing only a single internode with one pair of leaves before terminating in an inflorescence (Majure et al. 2013). Additionally, the thickened bases of the elongated hairs on the adaxial leaf surface (Fig. 1 I) may be synapomorphic. Many members of this group also bear an ovary crown, and some also have torus hairs. Exclusively continental relatives of M. strigillosa and M. dependens include species such as Clidemia pustulata DC., C. biserrata DC., C. urceolata DC., and C. novemnervia (DC.) Triana (Michelangeli et al., submitted), and perhaps also the phenetically similar C. siapensis Wurdack. [Names in Clidemia are used, here and elsewhere, for continental species lacking combinations in Miconia.] The M. octona clade (=Clidemia sect. Staphidium) is supported by the potential synapomorphies of pseudolateral inflorescences (Fig. 1 A, B, E, F), shoots producing only a single pair of leaves before terminating in an inflorescence (both likely evolved in parallel with the species of the $M$. 
strigillosa clade), the presence of torus hairs, and ovaries with five locules (Majure et al. 2013). Support is also provided by DNA-sequence characters (Michelangeli et al., submitted). Their leaves usually lack stellate hairs abaxially (although such hairs may be present on the major veins, and we note that such hairs are present even on the lamina of some species, e.g., M. octona). Additionally, the elongated hairs on the adaxial leaf surface are not bulla-based. Continental relatives include C. laevifolia Gleason and C. dentata D. Don (Michelangeli et al., submitted), and perhaps also C. acurensis Wurdack. The species of the Octopleura clade are easily differentiated from those of the M. strigillosa and M. octona clades because their stamens have an anther connective that is prolonged dorso-basally, forming a gland-edged appendage, and their hypanthia and mature berries are longitudinally ribbed (Gamba \& Almeda 2014).

Although it is clear that the species of the Miconia octona and M. strigillosa groups should be included within Miconia s.l., a detailed presentation of their taxonomic placement and infrageneric nomenclature must await an investigation of these Antillean species in the context of their continental relatives. However, their specific distinctions are already clear, they are recognized in many floristic treatments (e.g., Alain 1957; Almeda 2009; Gleason 1939; Liogier 1995, 2000; Michelangeli \& Bécquer 2012; Proctor 1972; Wurdack 1973, 1980), and are presented in the following dichotomous key (based upon the study of numerous herbarium specimens from the Greater Antilles). The most useful characters distinguishing these two groups (as evidenced in the key) are the presence of bulla-based hairs on the adaxial leaf surface in species of the M. strigillosa clade, vs. their absence in members of the M. octona clade, along with the presence vs. absence of an ovary crown. Additionally, the leaves of species of the M. strigillosa clade are usually stellate-pubescent beneath, while those of the M. octona group often lack such hairs on the abaxial surface of the lamina. Note that M. octona is an exception, having stellate hairs abaxially (see key).

In the taxonomic section below, we present an updated nomenclature for each of the Antillean species of the Miconia octona and M. strigillosa groups, along with an identification key and brief statements relating to their geographical distributions. Although morphologically variable, these species are phenetically distinct and easily distinguished - and, except for M. dependens, they show no significant internal morphological discontinuities in the Greater Antilles. Miconia dependens is exceptionally variable, such that infraspecific taxa have frequently been recognized within it (and infraspecific taxa have also been recognized within M. crenata and M. octona, relating to variation in continental regions). Perhaps some of these deserve specific recognition, but a detailed consideration of the pattern of variation within this broadly distributed species is beyond the scope of this article, which is focused on the populations of the Greater Antilles. The complex pattern of variation within $M$. dependens is unsurprising, given that the species is agamospermic and likely comprises a series of asexual entities (Melo et al. 1999). We note that agamospermy has also been recorded for M. crenata (Caetano 2014).

Chromosome numbers within the tribe Miconieae are remarkably uniform and usually represented by $n$ = 17 (Almeda 2013; Solt \& Wurdack 1980). These species, however, do show some variation in chromosome number, i.e., Miconia crenata $(n=17)$, M. dependens $(n=17)$, M. erythropogon $(n=15)$, M. octona $(n=17)$, and M. strigillosa ( $n=$ ca. 25-27) (Missouri Botanical Garden 2007; Solt \& Wurdack 1980). This unusual level of variability for the tribe may correlate with the occurrence of asexuality in these taxa.

\section{TAXONOMIC TREATMENT}

Key to Greater Antillean species of Miconia with conspicuous multicellular, elongate, simple, eglandular or gland-headed hairs, pseudolateral inflorescences, and flowers with elongated calyx teeth, 5 to 8, white, rounded petals, white, ovate anthers, and purple- or blue-black fruits.

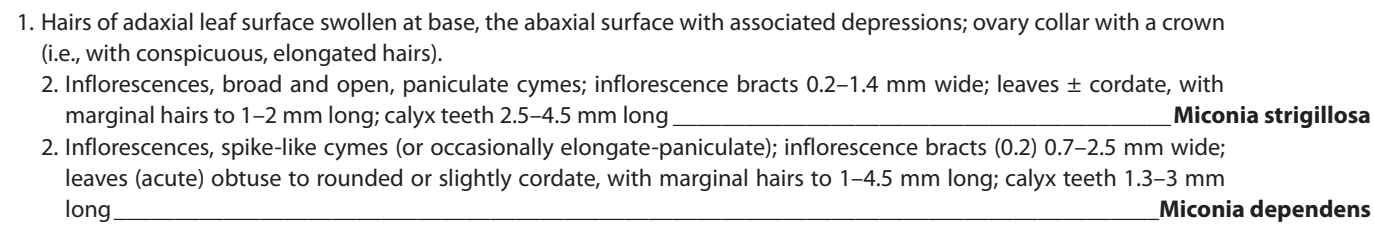


1. Hairs of adaxial leaf surface not swollen at base, the abaxial surface \pm flat; ovary collar, although lobed, without a crown.

3. Abaxial leaf surface with conspicuous stellate hairs; flowers with 5-8 petals

Miconia octona

3. Abaxial leaf surface lacking stellate hairs, although a few such hairs may be present on the major veins; flowers with

5-6 petals.

4. Leaves ovate, the base rounded to cordate, the length/width quotient 1.3-2.1; inflorescences \pm pedicellate, laxly branched; calyx with elongate, white, pale green, brownish to reddish hairs

4. Leaves ovate to elliptic or oblong, the base obliquely cuneate, obtuse, to rounded or slightly cordate, the length/ width quotient 1.9-3; inflorescences \pm sessile, densely short-branched; calyx with elongate, consistently bright red hairs

Miconia erythropogon

Clidemia D. Don. Mem. Wern. Nat. Hist. Soc. 4:284, 306, 307. 1823. Lectotype, here designated:Clidemia neglecta D. Don.

While describing Clidemia, Don (1823) included in it 19 different species, but none of them were designated as the type, as this was not a requirement at the time. Britton and Wilson (1925) mentioned C. neglecta as the type of Clidemia, presumably because it was the first species in Don's treatment. However, their designation of this species as the type was automatic and thus invalid. Here we formalize the selection of Clidemia neglecta (now considered a synonym of Miconia dependens) as the type of Clidemia. All of the generic characters used by Don are present in the type of this species.

\section{Species of the Miconia octona group in the Antilles:}

1. Miconia crenata (Vahl) Michelang. in Mabberley, Mabberley's Plant-Book, $4^{\text {th }}$ ed., p. 1102. Cambridge, U.K. 2017 (Fig. 1 A-C). Melastoma crenatum Vahl, Eclog. Amer. 1:41. 1797. Type: BraziL: without definite locality, P. Commerson s.n. (ноцотүре: C 10014542 [digital image!]).

Melastoma hirtum L., Sp. Pl. 390. 1753. Clidemia hirta (L.) D. Don, Mem. Wern. Nat. Hist. Soc. 4:309. 1823. Maieta hirta (L.) M. Gómez, Anales Hist. Nat. 23:70. 1894. Type: Jamaica: without definite locality, P. Browne s.n. (LECtotype, designated by R.A. Howard, 1989: LINN 559.2!). Non Miconia hirta Cogn. in Rusby, Mem. Torrey Bot. Club 3 (3):31. 1893.

Melastoma elegans Aubl., Hist. Pl. Guiane 1:427, t. 167. 1775. Type: French Guiana: without definite locality, J.B.C.F. Aublet s.n. (hOLOTYPE: BM 001008286 [digital image!]). Non Miconia elegans Cogn. Fl. Bras. (Martius) 14(4): 312. 1887.

Melastoma pauciflorum Desr. in Lam., Encyc. 4:39. 1797/98. TyPE: BrAzIL: near Rio de Janeiro, from the herbarium of D. Dombey (not seen, but possibly at K). Non Miconia pauciflora Triana, Trans. Linn. Soc. London 28:115. 1871.

For a complete listing of synonyms see Cogniaux (1891) and Renner et al. (2007-2017).

Distribution.-Within the Greater Antilles, Miconia crenata occurs in Cuba, Hispaniola (both the Dominican Republic and Haiti), Jamaica, and Puerto Rico (Alain 1957; Axelrod 2011; Liogier 1995, 2000; Proctor 1972), and it also grows in the Virgin Islands (St. Thomas, Tortola) and Lesser Antilles (Antigua, Dominica, Grenada, Guadeloupe, Martinique, Montserrat, Nevis, St. Kitts, St. Lucia, St. Vincent) (Howard 1989; Michelangeli \& Bécquer 2012). The species is also widely distributed in the continental Neotropics, occurring in North America (Mexico) through Central America to northern and central South America. The species has become an aggressive and invasive shrub on many Pacific islands (e.g., Hawaii and Fiji; Almeda 1990; Simmonds 1937; Wester \& Wood 1977), at scattered locations in the Asian tropics, in northeastern Australia, Madagascar, islands in the Indian Ocean, and in eastern Africa (e.g., see Peters 2001; CABI 2017).

This species was transferred to Miconia as M. crenata because the epithet "hirta" is already preoccupied in Miconia. Similarly, two other epithets of early heterotypic synonyms were also occupied. The earliest epithet available in Miconia corresponds to Melastoma crenatum.

2. Miconia erythropogon (DC.) Judd \& Ionta, comb. nov. (Fig. 1 D-G). Clidemia erythropogon DC., Prodr. 3:157. 1828. Type: JAmaica: without definite locality, C.L.G. Bertero s.n. (hоLотYPE: G-DC 002201725 [digital image!]; photo of specimen: F!).

Staphidium wilsonii Naudin, Ann. Sc. Nat. Ser. 3 17:311. 1852. Type: Jamaica: without definite locality, Wilson 11 (LectotyPE, here designated: P 04022818 [digital image!]; ISOLECTOTYPE: K! [K000536825])

Staphidium wilsonii var. crinitum Naudin, Ann. Sci. Nat. Bot. ser. 3 17:311. 1852. TypE: Cuba: prope Santiago et Nima-nima, J.J. Linden 2092 (LECTOTYPE, here designated: P 040422819 [digital image!]; ISOLECTOTYPEs: GENT 0000013074074 [digital image!], P 040422820 [digital image!])

Nomenclatural note.-Wright 178 is a mixed collection of Cuban plants, and the specimen at BR (5184712, digital image!) is the lectotype of Clidemia capituliflora Cogn. in A.L.P.P. de Candolle \& A.C.P. de Candolle (Monogr. Phan. 7:1021. 1891); however, the duplicates of Wright 178 at GH! (with the original collection label, i.e., from Monte Verde) and K (536915, digital image!), represent Miconia erythropogon. The name C. capituliflora, therefore, is not considered a synonym of M. erythropogon. 

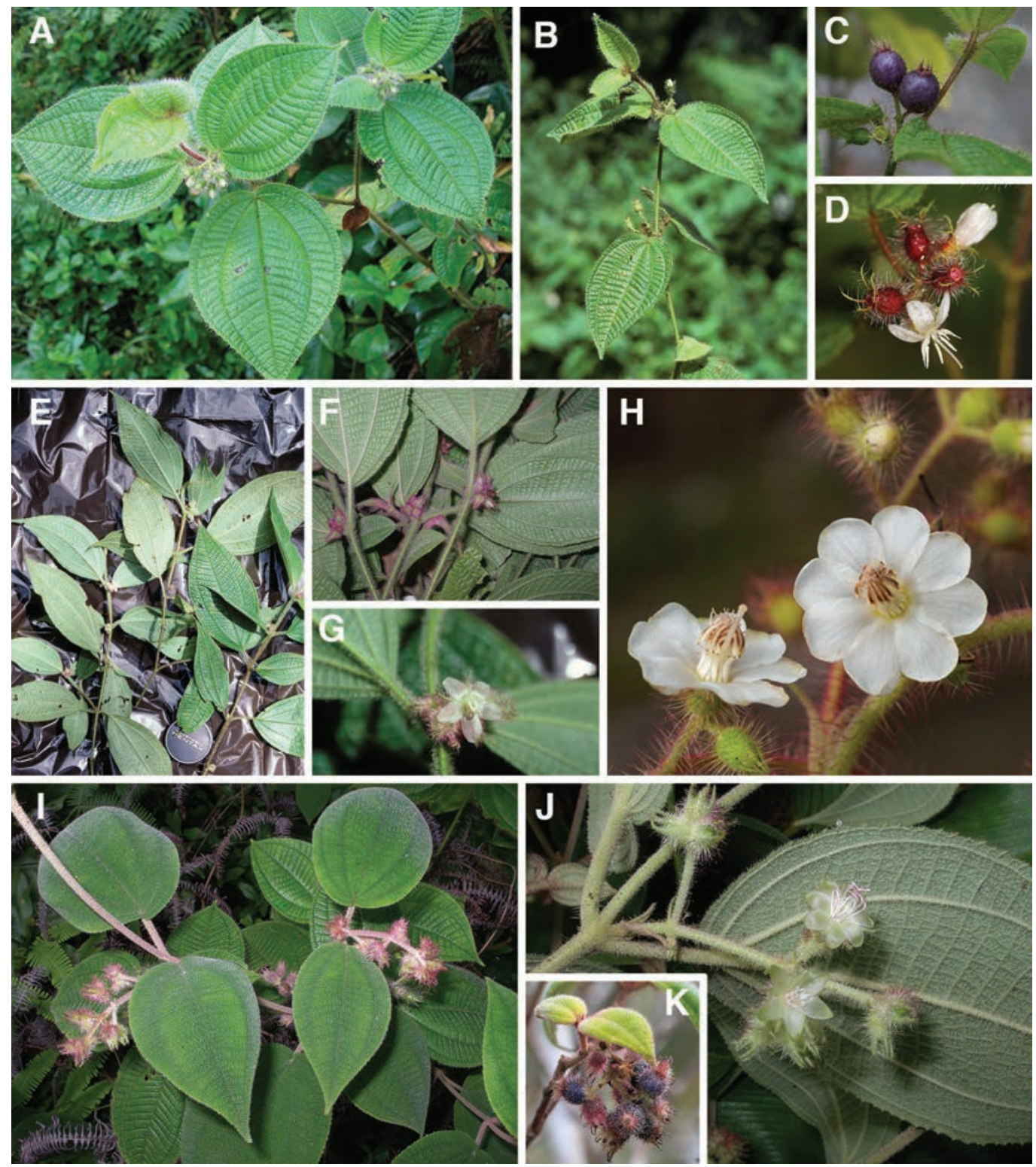

Fig. 1. Miconia crenata and close relatives. A. M. crenata showing habit and inflorescence structure (Bath Fountains, Jamaica). B. M. crenata showing sympodial growth, with terminal inflorescences deflexed to seeming axillary position (Judd 3057; and photo previously published in Judd, 1986, fig. 5). C. Fruits of $M$. crenata (Majure 6044). D. Inflorescence and flowers of M. erythropogon (Wakefield, Jamaica). E-F. Habit and inflorescence structure of $M$. erythropogon (Judd 5246 and Judd 8299). G. Flower of M. erythropogon (Judd 5246). H. Flower showing typical eight petals of M. octona (Michelangeli 1750). I. Habit and inflorescence structure of M. strigillosa (Judd 8338).J-K. Flowers (Judd 8338) and fruit (Mason River, Jamaica) of M. strigillosa. Photos B, E-G, and I-J taken by W.S. Judd; D and K taken by G.M. Ionta; A taken by J.D. Skean, Jr; $\mathrm{H}$ taken by F.A. Michelangeli; and $\mathrm{C}$ taken by L.C. Majure. 
Distribution.-Miconia erythropogon is endemic to the Greater Antilles, occurring only in Jamaica, Cuba (in the Sierra Maestra and Sierra de Moa), and Hispaniola (Dominican Republic, at Valle Flores, and Haiti, in the Massif de la Hotte) (Alain 1957; Liogier 2000; Proctor 1972). This species is morphologically similar to its close relative, the widespread M. crenata, but the two species may be consistently distinguished by the characteristics provided in the key. The species has also been recognized by other systematists, e.g., Alain (1957), Proctor (1972), and Michelangeli and Bécquer (2012).

3. Miconia octona (Bonpl.) Judd \& Majure, comb. nov. (Fig. 1 H). Melastoma octonum Bonpl., Melast. 1:t. 4. 1806. Heterotrichum octonum (Bonpl.) DC., Prodr. 3:173. 1828. Staphidium octonum (Bonpl.) Naudin, Ann. Sci. Nat., Bot., ser. 3, 17(5):306. 1851. Stephanotrichum octonum (Bonpl.) Naudin ex Hemsl., Biol. Cent.-Amer., Bot. 1(5):430. 1880. Clidemia octona (Bonpl.) L.O. Williams, Fieldiana, Bot. 29:558. 1963. Type: Colombia: monte Quindiu, juxta fluvium Guadas, Humboldt \& Bonpland 1745. (P, not seen [apparently three duplicates under this number], BM 001008226 [digital image!]).

Heterotrichum octonum var. brasiliensis Cogn., Fl. Bras. (Martius) 14 (4):429. 1888. Type: BraziL: Rio de Janeira, Barra de Tiquitiba, Riedel 829 (LестотуPE, here designated: P 02090269 [digital image!]). Remaining syntypes: Minas Gerais, Conceicao, Pohl 446 (not seen), Pohl 1517 (not seen).

Clidemia pilosissima Cogn. ex Britton, Bull. Torrey Bot. Club 17(8):211. 1890. Type: Bolivia: Mapiri, 5000 ft, May 1886, H.H. Rusby 2234 (HOLOTYPE: NY! [NY 00221576]; ISOTYPES: LP 010590 [digital image!], MICH 1111790 [digital image!], US! [US 00123637])

Distribution.-Miconia octona is found only in Cuba and Jamaica within the Greater Antilles (Alain 1957; Proctor 1972); it does not occur in the Lesser Antilles. The species is widespread in the continental Neotropicsgrowing in North America (Mexico), Central America, and South America as far south as Bolivia.

\section{Species of the Miconia strigillosa group:}

4. Miconia strigillosa (Sw.) Judd \& Ionta, comb. nov. (Fig. 1 I-K). Melastoma strigillosum Sw., Prodr. 71. 1788. Clidemia strigillosa (Sw.) DC., Prodr. 3:159. 1828. Clidemia spicata var. strigillosa (Sw.) Griseb., Fl. Brit. W.I. 3:247. 1860. Type: Jamaica: without definite locality, O.P. Swartz s.n. (LECTOTYPE, here designated: S 14-17934 [digital image!]).

Clidemia tristis D. Don, Mem. Wern. Nat. Hist. Soc. 4:307. 1823. Type: Peru: J.A. Pavón s.n. (not seen, possibly at OXF).

Clidemia umbonata Schr, et Mart. ex DC., Prodr. 3:158. 1828. Type: BraziL: Rio Negro ad Nogueira, C.F.P. von Martius. s.n. (HOLOTYPE: M 0165406 [digital image!]; IsотуPEs: G-DC 00310639 [fragment; digital image!], M 0165407 [digital image!]).

Distribution.-Within the Greater Antilles, Miconia strigillosa occurs on Cuba, Hispaniola (Dominican Republic and Haiti), Puerto Rico, and Jamaica (Alain 1957; Axelrod 2011; Liogier 1995, 2000; Proctor 1972). It is absent from the Lesser Antilles. The species is also widespread in continental regions of the Neotropics, growing in Central America and northern South America, extending south to Peru.

5. Miconia dependens (D. Don) Judd \& Majure, comb. nov. Clidemia dependens Pavón ex D. Don, Mem. Wern. Nat. Hist. Soc. 4:307. 1823. Maieta dependens (D. Don) Baill., Hist. Pl. 7:35. 1877. Clidemia capitellata (Bonpl.) D. Don var. dependens (D. Don) J.F. Macbr, Publ. Field Mus. Nat. Hist., Bot. ser. 13, pt. 4:484. 1941. Type: Peru: without definite locality, J.A. Pavón s.n. (LECTOTYPE, here designated: MA 813796 [digital image!]; possible isolectotype probably also at OXF).

Melastoma spicatum Aubl., Hist. Pl. Guiane 1:423. 1775. Clidemia spicata (Aubl.) DC., Prodr. 3:159. 1828 (non C. spicata Don, Mem. Wern. Nat. Hist. Soc. 4:308. 1823). Maieta spicata (Aubl.) M. Gómez, Anales Hist. Nat. 23:70. 1849. Staphidium spicatum (Aubl.) Naudin, Ann. Sci. Nat., Bot., Ser. 3, 17:316. 1852. Type: French Guiana: Courou [Kourou], J.B.C.F. Aublet s.n. (holotype: BM 001008384 [digital image!]; ISOTYPEs: MPU 014083 [digital image!], P 00678330 [digital image!]). Non Miconia spicata (Gleason) Gamba \& Almeda, Phytotaxa 357(4): 298. 2018

Melastoma capitellata Bonpl., Mélast. 5, pl. 3. 1806. Clidemia capitellata (Bonpl.) D. Don, Mem. Wern. Nat. Hist. Soc. 4:310. 1823. Type: Colombia: inter Fusagasuga et Pandi, Humboldt \& Bonpland 1720 (HоLотуPE: P 04022758 [digital image!]; Isotypes: BM 001008282 [digital image!], P 04022759 [digital image!]). Non Miconia capitellata Cogn. (1891).

Clidemia neglecta D. Don, Mem. Wern. Nat. Hist. Soc. 4:307. 1823. Clidemia capitellata Bonpl. var. neglecta (D. Don) L.O. Williams, Fieldiana, Bot. 29:556. 1963. Type: Peru: without definite locality, J.A. Pavón s.n. (LEctotyPe, here designated: MA 813791 [digital image!]; ISOLECTOTYPE: B, destroyed; PHOTO OF ISOLECTOTYPE: F OBNO17232 [digital image!], possible isoleCtOTYPE: MA 813790 [digital image!]).

Staphidium confertiflorum Naudin, Ann. Sci. Nat. Bot. Ser. 3. 17:318. 1851. Type: Mexico: near Oaxaca, 3000 ft, H.G. Galeotti 2957 (HоLотуре: P 04022835 [digital image!]; ISOTYPEs: BR 0000005184828 [digital image!], US!).

Staphidium bracteosum Naudin, Ann. Sci. Nat. Bot. Ser. 3. 17:318. 1851. Type: French GuiAna: 1838, Leprieur s.n. (holotype: P 04022836 [digital image!]). 
Clidemia subspicata Beurl., KongI. Vetensk. Acad. Handl. 1854:126. 1856. Type: Panama: Portobello, Apr 1826, J.I. Billberg 272 (ноцотурE: S!; ISOTYPE: MO 102462 [digital image!]).

Distribution.-Within the Greater Antilles Miconia dependens grows only in eastern Cuba (Pinar del Río, Isla de Pinos), and a single specimen, possibly mislabeled, exists from Jamaica (Alain 1957; Proctor 1972); the species is absent from the Lesser Antilles. It is widely distributed in the Neotropics, occurring in North America (southern Mexico), throughout Central America, and in northern South America.

\section{ACKNOWLEDGMENTS}

We thank Norris Williams, Keeper of the University of Florida Herbarium (FLAS) and Kent Perkins, Collections Manager (FLAS), for assistance in processing and use of specimens. We thank the curator and staff of the herbarium of the New York Botanical Garden (NY) for their generous loan of specimens. Keron C. St. E. Campbell graciously assisted in the visit of the first and second authors to the herbarium (IJ) of the Natural History Museum of Jamaica, Institute of Jamaica. Milcíades Mejia, Thomas A. Zanoni, Daisy Castillo, Alain H. Liogier, Teodoro Clase, Ricardo García, Francisco Jiménez, and Brigido Peguero assisted in several visits of the first and third authors to the herbarium (JBSD) of the Jardin Botánico Nacional, Dominican Republic. We appreciate the very useful comments of two reviewers: Frank Almeda and Darin Penneys. This research was supported, in part, by National Science Foundation Grant BSR-0818399.

\section{REFERENCES}

Alain, Bro. (= A.H. Liogier). 1957. Flora de Cuba. Vol. 4. Dicotiledóneas: Melastomataceae a Plantaginaceae. Cont. Ocas. Mus. Hist. Nat. Col. “De La Salle." Havana.

AlmedA, F. 1990. Miconia. In: Wagner, W.L., D.R. Herbst, \& S.H. Sohmer. 1990. Manual of the flowering plants of Hawaii. Bishop Museum Special Publication 83. University of Hawaii Press, Bishop Museum Press, Honolulu, Hawaii, U.S.A.

AlmedA, F. 2009. Melastomataceae. In: G. Davidse, M. Sousa-Sánchez, S. Knapp, \& F. Chiang, eds. Flora Mesoamericana 4(1). Universidad Nacional Autónoma de México, México. Pp. 164-338.

AlmedA, F. 2013. Systematic and phylogenetic significance of chromosome number diversity in some Neotropical Melastomataceae. Mem. New York Bot. Garden 108:167-189.

Axelrod, F.S. 2011. A systematic vademecum to the vascular plants of Puerto Rico. Sida Bot. Misc. 34:1-428.

BritTon, N. \& P. WiLson. 1925. Melastomataceae in scientific survey of Porto Rico and the Virgin Islands. New York Acad. Sci. 6:1-18.

CABI. 2017. Clidemia hirta. By J. Rojas-Sandoval \& P. Acevedo-Rodriguez. In: Invasive species compendium. CAB International, Wallingford, U.K. wwW. cabi.org/isc.

Caetano, A.P. De SouzA. 2014. Contribuięão da embriologia na sistemática e na elucidaęão da apomixia em Melastomataceae Juss. Thesis. Campinas. http://repositorio.unicamp.br/jspui/handle/REPOSIP/3155575.

Cogniaux, A. 1891. Melastomataceae. In: A. de Candolle \& C. de Candolle, eds. Monographiae phanerogamarum 7. Masson, Paris, France. Pp. 1-1256.

CROAT, T.B. 1978. Flora of Barro Colorado Island. Stanford University Press, Stanford, California, U.S.A.

Don, D. 1823. XXIV. An illustration of the natural family of plants called Melastomaceae. Mem. Wernerian Nat. Hist. Soc. $4: 276-329$.

Gamba, D. \& F. Almeda. 2014. Systematics of the Octopleura clade of Miconia (Melastomataceae: Miconieae) in Tropical America. Phytotaxa 179:1-174.

Gleason, H.A. 1939. The genus Clidemia in Mexico and Central America. Brittonia 3:97-140.

Goldenberg, R.D., D.S. Penneys, F. Almeda, W.S. Judd, \& F.A. Michelangeli. 2008. Phylogeny of Miconia (Melastomataceae): Patterns of stamen diversification in a megadiverse Neotropical genus. Int. J. PI. Sci. 169:963-979.

Goldenberg, R., F. Almeda, M.K. Caddah, A.B. Martins, J. Meirelles, F.A. Michelangeli, \& M. Weiss. 2013. Nomenclator botanicus for the Neotropical genus Miconia (Melastomataceae: Miconieae). Phytotaxa 106:1-171.

Howard, R.A. 1989. Flora of the Lesser Antilles: Leeward and Windward Islands. Vol. 5. Dicotyledoneae - Part 2. Arnold Arboretum, Harvard Univ., Jamaica Plain, Massachusetts, U.S.A.

IonTA, G.M., W.S. Judd, J.D. SkEAN, JR., \& C.K. McMullen. 2012. Two new species of Miconia sect. Sagraea (Melastomataceae) from the Macaya Biosphere Reserve, Haiti, and twelve relevant new species combinations. Brittonia 64:61-72. 
JuDD, W.S. 1986. Taxonomic studies in the Miconieae (Melastomataceae). I. Variation in inflorescence position. Brittonia 38:150-161.

JudD, W.S. 1989. Taxonomic studies in the Miconieae (Melastomataceae). III. Cladistic analysis of axillary-flowered taxa. Ann. Missouri Bot. Gard. 76:476-495.

JUDD, W.S. \& J.D. SKEAN, JR. 1991. Taxonomic studies in the Miconieae (Melastomataceae). IV. Generic realignments among terminal-flowered taxa. Bull. Florida Mus. Nat. Hist., Biol. Sci. 36:25-84.

Judd, W.S., E.R. Bécquer, \& L.C. Majure. 2014a. Taxonomic studies in the Miconieae (Melastomataceae). XI. A revision of Miconia sect. Calycopteris on Hispaniola. Brittonia 66:216-249.

Judd, W.S., E.R. Bécquer, J.D. SkeAn, JR., \& L.C. Majure. 2014b. Taxonomic studies in the Miconieae (Melastomataceae). XII. Revision of Miconia sect. Miconiastrum, with emphasis on the Miconia bicolor complex. J. Bot. Res. Inst. Texas 8:457-491.

Judd, W.S., L.C. Majure, J.D. SkeAn, JR., \& K.M. Neubig. 2015. Miconia abscondita (Melastomataceae: Miconieae), a new species from the Massif de la Hotte, Haiti: Rediscovered in herbaria after being hidden for nearly nine decades. Rhodora 117:317-341.

Liogier, H.A. (= A.H. LIogier). 1995. Descriptive flora of Puerto Rico and adjacent islands. Vol. 4. Melastomataceae to Lentibulariaceae. Universidad de Puerto Rico, Rio Piedras, Puerto Rico.

Lıogier, A.H. 2000. La flora de la Española, Vol. 9. Melastomataceae. Jardín Botánico Nacional “Dr. Rafael Ma. Moscoso," Instituto Tecnológico de Santo Domingo (INTEC), Santo Domingo.

Majure, L.C., W.S. Judd, G.M. Ionta, J.D. Skean, Jr., E.R. Bécquer, J. Burke, D.S. Penneys, G. Ocampo, M. Alvear, M. Goldenderg, R. Almeda, \& F. Michelangelı. 2013. Evaluating morphological evolution in tribe Miconieae (Melastomataceae): Homoplasy is the rule not the exception. Botany 2013. Abstract ID 300.

Majure, L.C., W.S. Judd, G.M. Ionta, J.D. Skean, JR., K.M. Neubig, \& E.R. Bécquer. 2014. Miconia cineana, a new species from the Massif de la Hotte, Haiti, based on morphological and molecular evidence. Syst. Bot. 39:906-914.

Martin, C.V., D.P. Little, R. Goldenberg, \& F.A. Michelangeli. 2008. A phylogenetic evaluation of Leandra (Miconieae, Melastomataceae) based on ITS data and its implications on inflorescence position. Taxon 53:279-290.

Melo, G.F., I.C. Machado, \& M. LuceÑo. 1999. Reprodución de tres especies de Clidemia (Melastomataceae) en Brasil. Rev. Biol. Trop. 47:359-363.

Michelangeli, F.A. \& E.R. Bécquer. 2012. Melastomataceae. In: P. Acevedo-Rodríguez \& M.T. Strong. Catalogue of seed plants of the West Indies. Smithsonian Contr. Bot. No. 98. Smithsonian Institution Scholarly Press, Washington, D.C. Pp. 531-652.

Michelangeli, F.A., D.S. Penneys, J. Giza, D.E. Soltis, M.H. Hils, \& J.D. Skean, JR. 2004. A preliminary phylogeny of the tribe Miconieae (Melastomataceae) based on ITS data and its implications on inflorescence position. Taxon 53:279-290.

Michelangeli, F.A., W.S. Judd, D.S. Penneys, J.D. Skean, JR., E.R. Bécquer, R. Goldenberg, \& C.V. Martin. 2008. Multiple events of dispersal and radiation of the tribe Miconieae (Melastomataceae) in the Caribbean. Bot. Rev. 74:53-77.

Michelangeli, F.A., F. Almeda, M. Alvear, E.R. Bécquer, J. Burke, M.K. Caddah, R. Goldenberg, G.M. Ionta, W.S. Judd, L.C. Majure, J. Meirelles, A.N. Nicolas, G. Ocampo, D.S. Penneys, J.D. Skean, Jr., \& C. Ulloa Ulloa. 2016. Proposal to conserve Miconia nom. cons. against the additional names Maieta and Tococa (Melastomataceae: Miconieae). Taxon 65:892-893.

Michelangeli, F.A., A.N. Nicolas, G. Ocampo, R. Goldenberg, F. Almeda, W.S. Judd, E.R. Bécquer, J.D. Skean, JR., R. Kriebel, K. Sosa, M.K. Caddah, G.M. Ionta, D.S. Penneys, M. Alvear, J.M. Burke, L.C. Majure, \& M. Reginato. Submitted. Historical biogeography of the Neotropical tribe Miconieae (Melastomataceae) reveals a pattern of progressive colonization from Amazonia to other Neotropical forests. J. Biog.

Missouri Botanical Garden. 2007. Tropicos database. Missouri Botanical Garden, St. Louis, Missouri, U.S.A. www.tropicos. org.

Moscoso, R.M. 1943. Catalogus florae domingensis. Parte 1. Spermatophyta. Universidad de Santo Domingo, Santo Domingo.

Peters, H.A. 2001. Clidemia hirta invasion at the Pasoh Forest Reserve: An unexpected plant invasion in an undisturbed tropical forest. Biotropica 33:60-68.

Proctor, G.R. 1972. Melastomataceae. In: C.D. Adams. Flowering plants of Jamaica. Smithsonian Institution Press, Washington, D.C., U.S.A. Pp. 529-546.

Renner, S. S., F. Almeda, C. Ulloa, F.A. Michelangel, \& R. Goldenberg. 2007-2017. Melastomataceae Net. A site with information on the biodiversity of Melastomataceae. www.melastomataceae.net

Simmonds, H.W. 1937. The biological control of the weed Clidemia hirta, commonly known in Fiji as "The Curse." Fiji Agric. J. 8:37-39. 
Solt, M.L. \& J.J. WURDACK. 1980. Chromosome numbers in the Melastomataceae. Phytologia 47:199-220.

Standley, P.C. \& L.O. Williams. 1961. Melastomataceae. In: Flora of Guatemala. Fieldiana, Bot. 24(7), no. 4. Chicago Natural History Museum, Illinois, U.S.A. Pp. 407-525.

URBAN, I. 1921. Flora domingensis. Symb. Antill. 8:481-860.

Wester, L.L. \& H.B. Wood. 1977. Koster's curse (Clidemia hirta), a weed pest in Hawaiian forests. Environ. Conserv. 4:35-42. WURDACK, J.J. 1973. Melastomataceae. In: T. Lasser, ed. Flora de Venezuela. Vol. 8. Instituto Botanico, Direccion de Recursos Naturales Renovables, Ministerio de Agricultura y Cría, Caracas, Venezuela. Pp. 1-819.

WURDACK, J.J. 1980. Melastomataceae. In: G. H. Harling \& B. Sparre, eds. Flora of Ecuador. Vol. 13. University of Göteborg \& Riksmuseum, Stockholm, Sweden. Pp. 1-416. 